\title{
Academic Integrity Issues in Decided Cases in Malaysia
}

\section{Nadia Murshida Abd Azzis \& Roslinah Mahmud}

To Link this Article: http://dx.doi.org/10.6007/IJARBSS/v11-i12/11920

DOI:10.6007/IJARBSS/v11-i12/11920

Received: 14 October 2021, Revised: 17 November 2021, Accepted: 30 November 2021

Published Online: 11 December 2021

In-Text Citation: (Azzis \& Mahmud, 2021)

To Cite this Article: Azzis, N. M. A., \& Mahmud, R. (2021). Academic Integrity Issues in Decided Cases in Malaysia. International Journal of Academic Research in Business and Social Sciences, 11(12), 1964-1970.

\section{Copyright: (c) 2021 The Author(s)}

Published by Human Resource Management Academic Research Society (www.hrmars.com)

This article is published under the Creative Commons Attribution (CC BY 4.0) license. Anyone may reproduce, distribute, translate and create derivative works of this article (for both commercial and non0-commercial purposes), subject to full attribution to the original publication and authors. The full terms of this license may be seen at: $\underline{\text { http://creativecommons.org/licences/by/4.0/legalcode }}$

\section{Vol. 11, No. 12, 2021, Pg. $1964-1970$}

Full Terms \& Conditions of access and use can be found at http://hrmars.com/index.php/pages/detail/publication-ethics 


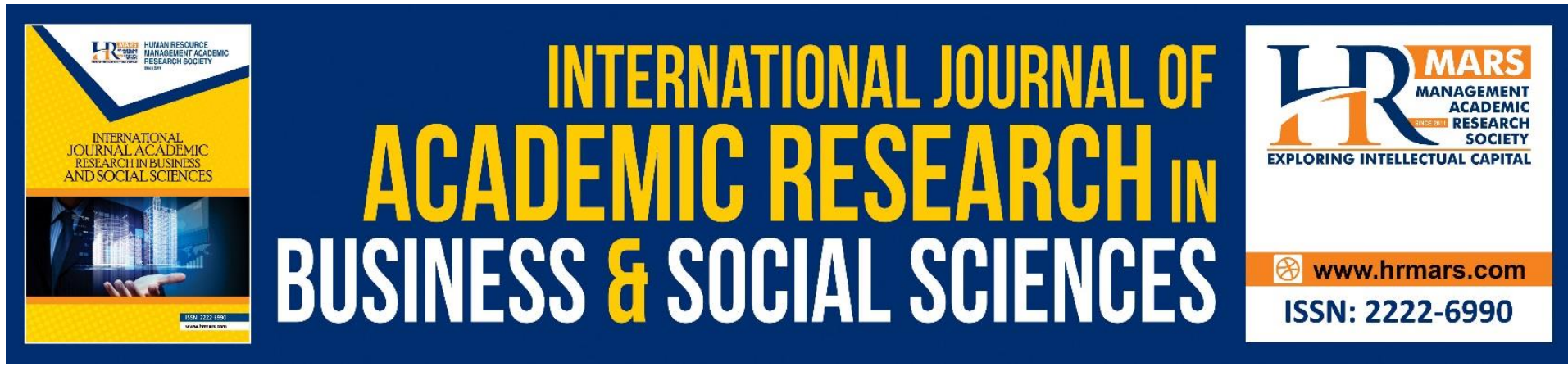

\title{
Academic Integrity Issues in Decided Cases in Malaysia
}

\author{
Nadia Murshida Abd Azzis ${ }^{1} \&$ Roslinah Mahmud ${ }^{2}$ \\ ${ }^{1}$ Faculty of Syariah \& Laws, Universiti Islam Antarabangsa Sultan Abdul Halim Mua'dzam \\ Shah, Kedah, Malaysia, ${ }^{2}$ Roslinah Mahmud \& Associates, Selangor, Malaysia \\ Email: nadiamurshida@unishams.edu.my, lenah_june@yahoo.com.
}

\begin{abstract}
A good writing has a reciprocal relationship with the researcher's discipline in accomplishing a research, analysing, elaborating, and presenting a prestigious publication coupled with a crystal-clear motive in producing an article journal. Discussing on the underlying principles in writing ethics, a researcher or an author observes a strict rule of academic integrity as well as research ethics in the era of information with divergent technology advances. Principles of academic integrity such as honesty, trust, transparency, and sincerity are the backbone in research writing. With regard to research ethics, etiquette such as permission to conduct research, confidentiality of data and compliance with the rules that have been given and agreed to seems to fulfil the moral values and Islamic values. The discussion of this article took an in-depth study with regard to the principles upheld by a researcher and author through library research including cases that have been decided in Malaysian court. The findings indicated that the components outlined in the principles of academic integrity and research ethics are appropriate in fulfilling the philosophy of Islamic values in producing a high-quality publication that gave rise to an intellectual property right on impactful published ideas.
\end{abstract}

Keywords: Research Ethics, Writing, Academic Integrity.

\section{Introduction}

With the advanced technology nowadays, researcher and author are equipped with various means to reach diversified information for data collection organized with the assistance of software tools in producing a high-quality product in presentation of their ideas. As a result, a robust research could be materialized by a dedicated researcher contributing whether to the body of knowledge or techniques of research methodology in an academic writing.

Referring to the researched area and expert area, an academic writing is guided with strong research objective, and prescribed limitation of study in answering the research questions. The accuracy of research content and ideas; proper arrangement of writing deliberation; selection of appropriate words; demonstration of language proficiency; formal and objective writing; and complete citation are among the criteria of a good writing. 
Among the purpose of academic writing is to delve deeper into the subject matter through various sources, established courage in transmitting knowledge out of the research results based on disciplines in a particular field and use appropriate approaches throughout the project. Simultaneously, a mindful researcher should build their character that might suits the principles in conducting a research for example generate and disseminate new knowledge and ideas by paying attention to the recognition of data sources; clarify the sources of information that lead to the new ideas; draw up the conclusions and theories based on existing ideas and previous studies; and lastly, make careful references to ensure reliability and validity that in line with the research objectives.

Another important point for a dedicated and committed researcher and author to produce a high-quality publication is by observing their self-discipline. The process of conducting research and writing is a challenge that assessed the abilities and capabilities of a researcher. Therefore, researchers need to have strong sense of responsibility and selfdetermination so that it will increase one's ability to complete a research project. Any lacking arose in the research journey especially in understanding certain debated issues should be identified and further study should be expounded. In addition, personal health, economic ability, and lifestyle are also contributing factors to the barriers to self-determination of a researcher (Khairulnizam \& Anwar, 2017; Pablo \& Lasaten, 2018). A researcher and author should have strong determination and motivation in accomplishing If these obstacles are not overcome, then this will weaken the spirit and self-motivation leading to laziness and despair.

\section{Research Methodology}

This research was conducted with the approach of exploratory and descriptive under qualitative study. Data were collected via library research including law reports journal for reference of decided cases in Malaysian Courts by way of purposive sampling method. Content analysis method is applied in data analysis of this research.

\section{Academic Integrity}

Academic Integrity in Academic Writing

Academic writing is an opportunity to delve into something that become a passion and interest of an author. Since the writer is free to choose the title for discussion, the writer is free to sketch out ideas and suggestions. The writer opens opportunity for the audience to read the author's thoughts and understand the information transmitted to them in a systematic style of writing. An author has no obligations to state all information available in his hand. Nonetheless, an author have to compose a piece of writing that demonstrates his comprehension of a topic and capability to present the research results based on his understanding. As such the process add value to an author in making objective research; evaluating the data and information obtained; organizing the process of writing; discussing an issue; analysing information; and expressing an opinion with dynamic argument (Khawlah, 2019).

According to Suryani and Sugeng (2019) the research found that with the rapid development of technology, the higher education institution have not yet grasped the idea of making available the academic integrity policy document or showing their integrity policies to the stakeholders. It is important as to prevent academic misconduct among the students and the users of the higher education institutions websites. The stakeholders benefited from the Google search engine and not from the higher education institution search engine in order to find documents and completing academic tasks. Whereas, referring to Sobre et. al (2017), 
individual characteristics and academic integrity policies have significant effect in mitigating academic dishonesty.

Commitment of a researcher and author, even in the face of adversity, have to bear these six fundamental values; honesty, trust, fairness, respect, responsibility, and courage (Khawlah, 2019; Khalidah et al., 2014). From these values, it flows principles of behaviours that enable academic communities to translate ideals into action. Principles of academic integrity such as honesty, trust, transparency and sincerity are the backbone of conducting a research writing (Zaman, et. al., 2020). In order to combat the wrong doings related to the issue of integrity and social media, a proper guideline or code of ethics in the work system should be established (Khawlah, 2019; Ariff et al., 2021). Research ethics such as permission to conduct research, confidentiality of data and compliance with the rules that have been set complement the perfection of a publication in line with Islamic values (Hanani, 2016; Hisham \& Burhan, 2019).

\section{Islamic Values}

A writing resulting from a research activity is intended to find the truth. A committed Muslim researcher will always conduct research within the framework of Islamic views (Hanani, 2016). This framework that will govern the focus, purpose, and method of conducting research. The finale of research is to attain the pleasure of Allah SWT, benefit oneself and others (Ramlan, 2017). As such, the aspects of epistemology, that is the knowledge that discusses the facts, sources and truths of knowledge; methodology, that is the science that studies the procedures or ways of knowing something and research methods that is a procedure that knows something that has systematic steps are important aspects that a researcher must have (Hisham \& Burhan, 2019).

Having understood that a writing is intended to disclose the truth; the truth and determination of the research will be of widespread benefit to various group of people (Noor Hisham \& Burhan, 2019). It is reasonable that the principles of honesty, trust, fairness, respect, responsibility, and courage are the principles that drive a high-quality research and writing. While research ethics such as obtaining permission to conduct research, maintaining the confidentiality of data and compliance with the rules that have been set indirectly give a special value to a research and writing from the Islamic perspective. So it is concluded that academic integrity and Islamic values are related, because a Muslim aimed for blessings that leads to widespread goodness and benefits (Hafizah et. al., 2020).

\section{Findings and Research Discussion}

Fauziah Salleh v. Universiti Malaysia Terengganu [2012] 4 CL 601

In the case of Fauziah Salleh v. Universiti Malaysia Terengganu, the plaintiff obtained a Master of Science in Finance from the defendant and was later offered a doctoral degree for three years from $23^{\text {rd }}$ July 2006 to $22^{\text {nd }}$ July 2009 . On $22^{\text {nd }}$ January 2007 , an investigation was conducted by the Investigation Department which demanded that the plaintiff appear as a witness. After a period of one year, the plaintiff received a letter dated $22^{\text {nd }}$ January 2008 from the defendant stating the revocation of the master's degree under Clauses 57 (1) (b) and 57 (2) of the University Constitution in respect of plagiarism. The plaintiff who was affected by the situation applied for a declaration from the court on the grounds that the defendant had violated Clause 57 of the University Constitution and the principle of natural justice.

The court ruled that the plaintiff's application was admissible. In this case there is no comprehensive discussion either on the guidelines of academic dissertation writing steps that 
should be followed by the plaintiff or provided by the defendants. The judge himself did not find that there was a complete set of writing guidelines provided by the defendants. In fact, based on the facts, there was no supervision of the plaintiff's writing from his own supervisor. The judge stated that, even if there is no complete guide to the writing from the university or faculty, the issue of plagiarism will not occur if the plaintiff's supervisor has supervised the plaintiff properly. Due to that, the Honourable Judge said that, even if the plaintiff was found guilty of committing the plagiarism, the defendant was partly liable for the act of plagiarism due to the defendant's failure to properly supervise the student. It is a must for an institution of higher learning to provide a complete guide in publishing an academic writing whether for the purpose of obtaining academic recognition at the diploma, first degree, master's degree or doctorate level, even at the laboratory research level, the findings of researchers should be revealed in the form writing for the purpose of documentation of search and data retrieval. The undeniable facts in this case, is that the plaintiff acknowledged the source of information used during the writing of the master's thesis, that is - the publication of Associate Professor Dr Nik Kamariah. In fact, the plaintiff mentioned the name of Associate Professor Dr. Nik Kamariah in the introduction of her thesis. During the court proceedings, the court found that $35 \%$ of the writings of Associate Professor Dr Nik Kamariah were in the plaintiff's thesis, as endorsed in the Investigating Committee Interview by the defendant's board. Plaintiff's acknowledged and have the full knowledge of the source of information obtained and it was not denied by plaintiff, therefore plaintiff believes that it is not necessary for plaintiff to make an acknowledgment through footnote to rewrite the source of reference of plaintiff's thesis. As such, plaintiff's failure to do so led to intellectual debt.

Sivapalan a/I Govindasamy v. University of Malaya [2020] 9 CLJ 638

While in the case of Sivapalan a/l Govindasamy v. University of Malaya, an appeal case against the decision of the High Court that rejected the application of a Sivapalan a/l Govindasamy (applicant) for judicial review. On $16^{\text {th }}$ October 1996, the applicant, a senior lecturer at the University of Malaya (respondent), registered with the respondent as a Doctor of Philosophy (PhD) candidate. After about nine years after PhD registration, the applicant submitted his thesis to the respondent on March $20^{\text {th }}, 2006$. The respondent submitted the applicant's thesis for examination to three examiners where they had recommended that the applicant be awarded a PhD. Subsequently, a viva voce of the applicant's PhD thesis that was held on $28^{\text {th }}$ September 2006 where members of the Examination Committee (JP) decided that the applicant's PhD thesis had achieved sufficient academic performance to be awarded a PhD provided the applicant made minor corrections, without re-examination, as recommended by the examiner, within a period not exceeding six months and confirmed by the supervisor/internal examiner. After the viva voce session, one of the EC members, Professor Dato Dr Mohammad Redzuan bin Othman realized there were suspicious circumstances in the reports of the two external examiners which raised issues about their credibility. Subsequently, a letter issued to the applicant dated $4^{\text {th }}$ December 2009 informing that the viva voce decision was quashed because the respondent's senate meeting had rejected the external and internal examiner's report.

The applicant then applied for judicial review (first judicial review) to challenge the decision. The High Court allowed the applicant's application for certiorari to quash the respondent's decision revoking the viva voce and the letter ruling that the applicant had failed his study. The respondent then instructed the Institute of Graduate Studies (IPS) to take the following steps to process the applicant's thesis; form a new JP, appoint a new examiner, and require the applicant to attend viva voce. In the absence of the applicant on $16^{\text {th }}$ March 2015, 
the JP proceeded with the viva voce and decided that the applicant's thesis required major corrections and submitted before $15^{\text {th }}$ September 2015 and if the applicant failed to do so, the applicant would fail his study.

The applicant challenged the decision of the JP in his second application of judicial review. The High Court allowed his application of certiorari to quash the respondent's decision and a declaration that the respondent to decide on the applicant's PhD degree based on the thesis submitted on $20^{\text {th }}$ March 2006 and the external and internal examiner's report relating to the thesis. Pursuant to the High Court order, the senate referred to the JP proposal on $28^{\text {th }}$ December 2006 where the applicant was asked to make corrections of his thesis within six months and the corrections would be confirmed by the applicant's thesis supervisor and further submitted before $28^{\text {th }}$ March 2017. The applicant was informed by IPS that his thesis must be dated 2017. The applicant however insisted that his thesis was dated 2006, as he claimed that he would be prejudiced in terms of his academic credibility. On March $28^{\text {th }}$, 2017, the applicant submitted his thesis dated 2006, without confirmation from his supervisor. On May $2^{\text {nd }}, 2017$, the senate informed the applicant that the thesis must be certified by a supervisor and dated 2017. The applicant refused to comply with the conditions set by the senate. On $23^{\text {rd }}$ June 2017, IPS informed the applicant that the senate recorded his failure as he fail to submit his final thesis with 2017 date within the stipulated time.

The applicant then filed the third judicial review application. In this time, the High Court is of the view that the respondent did not act irrationally, excessively, or unlawfully to allow the applicant's application for judicial review and the application sought and thus the applicant's application was dismissed. The Court dismissed the applicant's appeal with costs.

The court held that it is the exclusive jurisdiction of the university to determine whether a candidate has qualified for the award of a degree is an academic matter and cannot be disputed by the court. Furthermore, there was a convincing and substantial evidence to support the senate's decision to dismiss the applicant's thesis due to his non-compliance, including the presence of viva voce before the JP, confirmation of correction by the applicant's supervisor and the date of the applicant's PhD thesis as 2017 instead of 2006. Thus, it was certainly not irrational or unreasonable for the respondent senate to fail the applicant's PhD thesis.

A total of three judicial review applications filed by the applicant in this case and a total of three court judgments against the same application with the same order i.e., certiorari order quashing three decisions of the defendant who collectively ruled that the applicant had failed in his Phd examination.

Case Analysis

With regard to Fauziah's case, the element of academic integrity that arose is on the recognition or acknowledgment towards the original author in a specific manner that is through proper citation in footnoting section. It resembles on the value of honesty, trust, fairness, respect, and responsibility. Although the court ordered to reinstate the award and advantages that the plaintiff has received before, but, in the eye of principles in academic integrity, a researcher should observe strictly those values so that they are protected from any legal suits on the issue of infringement of intellectual property and copyright (Zaman, et. al., 2020). Cheating or "copying some paragraphs without citation" or copying words without credits amounts to dishonesty in academic and it is a form of plagiarism (Wheeler and Anderson, 2010; Marshall and Garry, 2005; Zaman et. al., 2020).

Under Islamic Law, cheating, plagiarism and all issues related to integrity and accountability development activity is the reflection of not observing the aqidah as-sahihah. 
It is because the concept of aqidah as-sahihah is a true concept of faith in the heart of man and absolutely drives to a harmonious and prosperous human life (Mokhtar et al., 2018).

Sivapalan's case has difference with Fauziah's case in term of principles of academic integrity from the scope of content of writing and process of examination. Although Sivapalan's case did not elaborate in detail on the 'suspicious' report received from the external examiner, but violation and manipulation of the examination process renders the whole script to be rejected and excluded as a precious and high value product. Compliance to relevant rules, guidelines, and direction from the authority (university) from time to time is crucial as to meet the needs prescribed by the controlling body. The term 'integrity' does not confine to only specific part of a job done by a researcher, but the definition covers the whole writing task whereby the concept of integrity measures the quality of being honest, having strong moral principles and upright of a researcher (Wiles, 2006; Shuhari et al., 2018).

\section{Conclusion}

The findings show that the components outlined in the principles of academic integrity and research ethics are seen as appropriate in fulfilling the philosophy of moral values and Islamic values in production of quality and high impact work which in return give rise to an intellectual property right on the published ideas.

\section{References}

Ariff, N. Z. Z. M., Kassim, N. A., Shoid, M. S. M., \& Baharuddin, K. (2021). Ethics and Integrity in Social Media. International Journal of Academic Research in Business and Social Sciences, 11(5), 310-318.

Khalidah, K. A., Rohani, S., \& Mashitah, S. (2014). Ethical values and commitment towards achieving excellence: A study on public boarding school students in Malaysia. Pertanika Journal of Social Sciences \& Humanities, 22, 33-50.

Ahmed, K. (2019): Academic integrity: Challenges and strategies for Asia and the Middle East, Accountability in Research.

Marshall, S., \& Garry, M. (2005). How well do students really understand plagiarism? ASCILITE 2005 - The Australasian Society for Computers in Learning in Tertiary Education, 457467.

Mokhtar, W. K. A. W., Khairuldin, W. M. K. F. W., Ibrahim, A., \& Embong, A. H. (2018). Al'AqīdațAl-Ṣahịhatas the Essential Element of Worldview of Development Integrity and Accountability. International Journal of Academic Research in Business and Social Sciences, 8(11), 328-337.

Shuhari, M. H., Hamat, M. F., Ismail, M. S., Jaffar, Y., Mustafa, M. F., \& Abdullah, M. S. (2018). Elements of Integrity within Muslim Individuals According to the Thought of al-Ghazali. International Journal of Academic Research in Business and Social Sciences, 8(10), 270278.

Suryani, A. W., \& Sugeng, B. (2019). Can you find it on the web? Assessing university websites on academic integrity policy. 2019 International Conference on Electrical, Electronics and Information Engineering (ICEEIE). doi:10.1109/iceeie47180.2019.8981.

Wheeler, D., \& Anderson, D. (2010). Dealing with plagiarism in a complex information society. Education, Business and Society: Contemporary Middle Eastern Issues, 3(3), 166-177.

Zaman, N. A. B., Yatin, S. F. M., Saad, N. S., Rashid, S. N., Kamis, Y., Abd Kadir, I. K., \& Dollah, W. Ab K.W. (2020). Plagiarism and Academic Integrity. International Journal of Academic Research in Business and Social Sciences. 10(11), 1138-1149. 